\title{
RESPON KRISIS KERATON KASUNANAN SURAKARTA DALAM MEDIA
}

\author{
RATNA WILANDARI \\ Program Studi Ilmu Komunikasi \\ Fakultas Komunikasi dan Informatika \\ Universitas Muhammadiyah Surakarta \\ Email : wilandarinana@gmail.com
}

\begin{abstract}
Crisis should be handled properly because it can threat the image and reputation of organizations if it is too late to be handled. The fulfillment needs the information in terms of responding crisis communication was very important to consider a lot of outstanding issues in the society at the time of crisis. Media was the fulfillment needs information that was important for the society. At the time of crisis organization or institution should understand that the news was published in the media containing specific massage. The reasearch method is content analysis that can be used to learn caracteristic features of message. The purpose of this study was determine whether there was differences election crisis communication response by category SCCT Theory in local media reports Solopos and Joglosemar period from februari until march 2014. The result showed that there was not difference in the election crisis communication response by SCCT Theory. This is evidenced by the data that the categorization of crisis response in the media Solopos was same categorization of crisis response found in Joglosemar media. Categorization crisis response is largest at Solopos that was Attack the accuser with 22 responses $(28,9 \%)$ of 76 crisis response that was found. Whereas Joglosemar with 12 responses (31,5\%) of 38 crisis response that was found. Response attack the accuser showed that the organization does not wanted to be blamed on the crisis, it is based on perspektive of the media.
\end{abstract}

Keywords : Crisis Communications, Content Analysis, Mass Media, Keraton, SCCT

\section{A. PENDAHULUAN}

Krisis banyak dialami oleh perusahaan maupun instansi. Manajemen komunikasi krisis perlu dilakukan untuk mencegah krisis yang berkelanjutan. Krisis merupakan fenomena yang terjadi secara tiba-tiba dan dapat menyerang perusahaan maupun instansi yang dapat menimbulkan ancaman baik reputasi organisasi, citra maupun finansial (Coombs, 2010).

Mengacu pada pernyataan yang dikemukakan oleh Benoit dalam jurnal komunikasi Coombs et al (2010), krisis merupakan ancaman terhadap reputasi perusahaan dan komunikasi respon krisis dapat menjadi bagian integral untuk memperbaiki reputasi dan aset-aset yang berharga bagi organisasi. Oleh karena itu, pemenuhan kebutuhan informasi atau dalam hal ini melalui pemberitaan di media adalah hal yang penting untuk diperhatikan. Penyebaran informasi yang cepat dan akurat menjadi prioritas utama dalam respon komunikasi krisis. Hal tersebut terkait dengan banyaknya isu yang beredar di publik pada saat terjadinya krisis. Oleh karena itu, media massa menjadi hal yang sangat penting karena mempunyai peranan dalam memberitakan setiap peristiwa. Para pemangku kepentingan dalam sejumlah krisis kecil juga belajar mengenai krisis melalui media massa baik elektronik maupun new media.

Pemberitaan mengenai konflik Keraton Surakarta menjadi hal yang ramai diperbincangkan setelah wafatnya PB XII pada tahun 2004 silam. Perebutan tahta untuk menjadi raja selanjutnya berlangsung cukup lama. Pemerintah juga ikut andil dalam masalah internal keraton tersebut. 
Mediasi-mediasi dilakukan oleh pemerintah baik dari pihak Pemkot Solo hingga presiden turun tangan terkait hal tersebut. Pendekatan yang dilakukan keraton untuk memperoleh pemecahan masalah yang baik berbeda dengan pendekatan yang dilakukan pada saat konflik atau krisis terjadi di lembaga atau organisasi lainnya. Hal ini karena keraton mempunyai hukum atau kebijakan yang sesuai dengan adat istiadat yang berlaku dan masih dipegang teguh oleh para pemangku kepentingan.

Dalam pemberitaan media massa, terdapat pesan-pesan yang telah melalui tahapan konstruksi terlebih dahulu. Konstruksi menurut $\mathrm{KBBI}$ merupakan susunan kata atau kalimat. Efek dari pemberitaan di media sangat kuat dan dapat menimbulkan persepsi publik yang sesuai dengan keinginan media massa. Berkaitan dengan hal tersebut maka peneliti tertarik untuk mengetahui bagaimana respon komunikasi krisis pemangku kepentingan pada saat krisis terjadi yang dikonstruksi oleh media atau dipublikasikan melalui media massa. Respon yang dipublikasikan melalui media massa berupa pemberitaan pada saat peristiwa terjadi. Strategi respon krisis yang peneliti gunakan mengacu pada teori situational crisis communication theory (SCCT). Berdasarkan teori tersebut, maka digunakan kategorisasi teori respon krisis yakni Attack the accuser (Menyerang /menyangkal), Denial (Menolak), Scapegoat (Menyalahkan), Excuse (Berdalih), Justification (Pembenaran), Apology (Permintaan maaf), Compensation (Ganti Rugi), Reminder (Mengingatkan), Ingratiation (Mengingatkan hal positif), dan Victimage (Korban).

Meninjau dari penelitian terdahulu yang berjudul Alitalia's Crisis in the MediaA Situational Analysis yang ditulis Rometie \& Valentini (2010) menggunakan metode analisis isi dan teori SCCT untuk menganalisis krisis yang terjadi melalui media nasional Italia dan media internasional. Hasil penelitian menunjukan dalam pemberitaan di media internasional pemerintah Itali melakukan siaran pers sesuai dengan realitas yang ada. Pada media nasional Italia, pemberitaan mengenai krisis tersebut yang dikeluarkan oleh pemerintah maupun maskapai mengandung unsur konstruksi media.

Sedangkan penelitian ini yang berjudul Respon Krisis Keraton Dalam Media (Studi Analisis Isi Respon Krisis Keraton Pada Media Solopos dan Joglosemar Periode Februari-Maret 2014) merupakan penelitian kuantitatif analisis isi dengan menggunakan kategorisasi teori SCCT untuk mengetahui respon krisis yang digunakan oleh pihak keraton. Pemilihan media lokal Solopos dan Joglosemar karena dua media tersebut termasuk media lokal terbesar di kota Solo.

Berdasarkan hal tersebut, maka rumusan masalah dalam penelitian ini adalah sebagai berikut :

1. Bagaimana harian Solopos dan Joglosemar menyajikan berita mengenai respon pihak internal keraton Surakarta terkait konflik yang terjadi pada bulan Februari - Maret 2014 berdasarkan kategorisasi teori respon krisis SCCT?

2. Apakah ada perbedaan pemilihan respon krisis keraton Surakarta dalam pemberitaan yang disajikan oleh harian Solopos dan Joglosemar?

\section{B. LANDASAN TEORI}

\section{Teori SCCT}

Penelitian ini menggunakan teori Situational Crisis Communication Teory (SCCT). SCCT merupakan teori respon krisis yang dicetuskan oleh W. Timoty Coombs (2007) dalam jurnal Protecting organization reputations during a crisis: The development and aplication of situational crisis communications theory. Teori tersebut merupakan teori perkembangan dari teori atribusi publik.

Secara garis besar, teori ini melihat bahwa krisis berdampak buruk pada seluruh aspek termasuk stakeholder. Selain itu, SCCT mengungkap ada pengaruh yang signifikan ketika stakeholder memberikan respon baik pernyataan maupun sikap 
yang ditunjukan dalam mengahadapi suatu krisis. SCCT menyediakan mekanisme untuk mengantisipasi cara para pemangku kepentingan akan bereaksi terhadap krisis dalam hal ancaman reputasi yang ditimbulkan. SCCT juga menjelaskan tentang cara orang akan bereaksi terhadap strategi respon krisis yang digunakan untuk mengelola krisis (Coombs, 2007).

SCCT mempunyai kategorisasi respon krisis sebagai berikut :

Tabel 1.1 Teori SCCT respon Krisis (Coombs, 2007)

\begin{tabular}{|c|c|c|}
\hline No & Kategori & Keterangan \\
\hline 1 & $\begin{array}{l}\text { Attack the } \\
\text { Accuser }\end{array}$ & $\begin{array}{l}\text { Mengemukakan kepada } \\
\text { orang lain bahwa ada ma- } \\
\text { salah dengan organisasi }\end{array}$ \\
\hline 2 & Denial & Merasa tidak ada masalah \\
\hline 3 & Scapegoat & $\begin{array}{l}\text { Menyalahkan orang lain/ } \\
\text { kelompok lain }\end{array}$ \\
\hline 4 & Excuse & $\begin{array}{l}\text { Berdalih untuk memi- } \\
\text { nimalisir dampak yang } \\
\text { ditimbulkan akibat krisis }\end{array}$ \\
\hline 5 & Justification & $\begin{array}{l}\text { Meminimalisir dampak } \\
\text { yang terjadi akibat krisis }\end{array}$ \\
\hline 6 & Apology & $\begin{array}{l}\text { Bertanggungjawab dan } \\
\text { meminta maaf }\end{array}$ \\
\hline 7 & $\begin{array}{l}\text { Compensa- } \\
\text { tion }\end{array}$ & Menawarkan kompensasi \\
\hline 8 & Reminder & $\begin{array}{l}\text { Mengingatkan karya- } \\
\text { karya organisasi }\end{array}$ \\
\hline 9 & Ingratiation & $\begin{array}{l}\text { Memuji prestasi organisa- } \\
\text { si }\end{array}$ \\
\hline 10 & Victimage & $\begin{array}{l}\text { Menyatakan bahwa mere- } \\
\text { ka korban }\end{array}$ \\
\hline
\end{tabular}

2. Analisis Isi

Analisis isi mempelajari mengenai isi teks media baik media cetak maupun elektronik. Selain itu, analisis isi juga dapat digunakan untuk mempelajari ranah ilmu komunikasi yang lain seperi komunikasi organisasi, komunikasi kelompok, komunikasi perusahaan, dan lainya asalkan mempunyai teks atau dokumen untuk diteliti.

Penelitian ini menggunakan analisis isi kuantitatif yang merupakan ranah aliran transmisi pesan. Oleh karena itu, tujuan dari analisis isi digunakan untuk mengetahui gambaran karakteristik bentuk isi pesan yang statis dan substansi isi pesan. Gambaran respon yang diberikan oleh pihak internal keraton merupakan sebuah substansi isi pesan.

\section{METODE PENELITIAN}

Metode yang digunakan dalam penelitian ini adalah content analysis. Peneliti menggunakan metode analisis isi karena dengan metode tersebut berita mengenai konflik Keraton Solo yang ditulis oleh media dapat memberikan gambaran dan karakteristik isi yang sesuai dengan fakta secara objektif.

Objek dalam penelitian ini adalah pemberitaan mengenai konflik yang terjadi di Keraton Kasunanan Surakarta pada media online Solopos.com dan Joglosemar. com bulan Februari - April 2014.

Dalam penelitian ini, populasinya adalah semua berita yang tersaji mengenai konflik Keraton Solo dari dua media lokal di Surakarta yakni Solopos dan Joglosemar. Pemberitaan diambil dari bulan Februari hingga April 2014. Hasilnya ada 21 berita mengenai konflik Keraton Solo. Sedangkan pemilihan sampelnya penulis memilih menggunakan sampel secara tidak acak atau non-probability karena populasi yang diperoleh tidak memungkinkan untuk dilakukan penarikan sampel secara acak.

\section{HASIL DAN PEMBAHASAN}

Berdasarkan pada tujuan penelitian yakni ingin melihat gambaran pesan berupa respon pihak internal keraton dalam media, maka data-data yang disajikan berupa tabel kategorisasi teori respon krisis SCCT. Dalam penelitian ini, alat ukur yang digunakan selain harus valid juga harus mempunyai keandalan yang tinggi (reliabilitas). Uji reliabilitas yang digunakan adalah formula Holsti dengan Rumus sebagai berikut:

$$
\mathrm{CR}=\frac{2 \mathrm{M}}{\mathrm{N} 1+\mathrm{N} 2}
$$


Rumus di atas menunjukan $\mathrm{M}$ adalah jumlah persetujuan dari kedua coder N1 (coder pertama) dan N2 (coder kedua). Dalam formula Holsti, angka reliabilitas umum yang ditoleransi adalah 0,7 atau $70 \%$, Artinya, jika hasil perhitungan menunjukan angka reliabilitas di atas 0,7 berarti alat ukur ini benar-benar reliabel, tetapi jika perhitungan yang didapatkan menunjukan angka reliabilitas di bawah 0,7 maka alat ukur yang digunakan tidak reliabel (Eriyanto, 2011 : 290).

Selanjutnya uji reliabilitas respon krisis dalam media Solopos dan Joglosemar yang telah dikategorisasikan berdasarkan teori SCCT disajikan sebagai berikut ini :

Tabel 1. Hasil Uji Reliabilitas Respon dalam Media Solopos

\begin{tabular}{|c|c|c|c|c|}
\hline No & Kategori Strategi Respon Krisis & N1 & N2 & M \\
\hline 1 & Attack The Accuser & 24 & 21 & 22 \\
\hline 2 & Denial & 6 & 6 & 6 \\
\hline 3 & Scapegoat & 8 & 6 & 7 \\
\hline 4 & Excuse & 24 & 15 & 19 \\
\hline 5 & Justification & 3 & 5 & 4 \\
\hline 6 & Apology & 7 & 9 & 8 \\
\hline 7 & Compensastion & 2 & 4 & 3 \\
\hline 8 & Reminder & 2 & 3 & 2 \\
\hline 9 & Ingratiation & 1 & 1 & 1 \\
\hline 10 & Victimage & 2 & 6 & 4 \\
\hline \multicolumn{2}{|c|}{ Jumlah } & 79 & 76 & 76 \\
\hline
\end{tabular}

(Sumber : Koding Peneliti)

Tabel 2. Hasil Uji Reliabilitas Respon dalam Media Joglosemar

\begin{tabular}{llccc}
\hline No & Kategori Strategi Respon Krisis & N1 & N2 & $\mathrm{M}$ \\
\hline 1 & Attack The Accuser & 14 & 11 & 12 \\
2 & Denial & 4 & 3 & 3 \\
3 & Scapegoat & 4 & 2 & 3 \\
4 & Excuse & 6 & 6 & 6 \\
5 & Justification & 4 & 3 & 3 \\
6 & Apology & 1 & 1 & 1 \\
7 & Compensastion & 2 & 4 & 3 \\
8 & Reminder & 3 & 2 & 2 \\
9 & Ingratiation & 1 & 1 & 1 \\
10 & Victimage & 4 & 4 & 4 \\
\hline Jumlah & & 43 & 37 & 38
\end{tabular}

(Sumber data pengkoding)

Berdasarkan hasil pengkodingan dan uji reliabilitas menggunakan rumus Holsti di atas, maka frekuensi yang muncul dari respon krisis Keraton Solo pada pemberitaan di Solopos.com periode bulan Februari hingga Maret 2014 yang menunjukan respon menyerang atau attack the accuser ada 22 kalimat dan presentasenya adalah $28,9 \%$. Perhitungan selengkapnya dapat dilihat pada tabel berikut ini:

Tabel 3. Distribusi Frekuensi Respon Krisis Keraton Solo Pada Pemberitaan di Solopos.com

\begin{tabular}{llll}
\hline No & \multicolumn{2}{l}{ Kategori Respon Frekuensi } & Persentase \\
& Krisis \\
\hline 1 & $\begin{array}{l}\text { Attack } \\
\text { cuser }\end{array}$ & & \\
\hline & & & \\
\end{tabular}




\begin{tabular}{llll}
2 & Denial & 6 & $7,89 \%$ \\
3 & Scapegoat & 7 & $9,21 \%$ \\
4 & Exuce & 19 & $25 \%$ \\
5 & Justification & 4 & $5,2 \%$ \\
6 & Apology & 8 & $10,5 \%$ \\
7 & Compensation & 3 & $3,9 \%$ \\
8 & Reminder & 2 & $2,6 \%$ \\
9 & Ingratiation & 1 & $1,3 \%$ \\
10 & Victimage & 4 & $5,2 \%$ \\
\hline
\end{tabular}

\begin{tabular}{lll}
\hline Jumlah & 76 & $100 \%$ \\
Tabel 5. Distribusi & Frekuensi Respon Krisis \\
Keraton Solo Pada Pemberitaan di \\
Joglosemar.com
\end{tabular}

(Sumber : Koding Penulis)

Berdasarkan hasil perhitungan peneliti terhadap kategori respon krisis Keraton Surakarta dalam media Solopos dan Joglosemar periode Februari - Maret 2014 menunjukan temuan bahwa kategori respon krisis (SCCT) yang paling banyak adalah kategori Attack the Accuser. Pada media Solopos terdapat 76 respon krisis dari semua kategorisasi yang telah disepakati oleh kedua coder. Kategori Attack the Accuser paling banyak ditemukan dengan 22 respon dengan persentase 28,9\%. Sedangkan pada media Joglosemar terdapat 38 respon krisis dari semua kategorisasi yang telah disepakati oleh kedua coder. Kategori Attack the Accuser paling banyak muncul dengan 12 respon dengan persentase
$31,5 \%$. Temuan tersebut menunjukan sikap dari pemangku kepentingan di Keraton Surakarta cenderung menyerang atau mengemukakan kepada orang lain bahwa terdapat masalah atau konflik dalam keraton yang belum terselesaikan. Selanjutnya, temuan respon krisis yang menunjukan nilai terbanyak di bawah respon Attack the Accuser adalah excuse. Hal tersebut berarti pemangku kepentingan juga menunjukan sikap berdalih atau beralasan. Strategi respon krisis itu juga dapat digunakan untuk menjelaskan salah satu faktor atau pemicu terjadinya krisis sebagai tindakan atas kontrol organisasi.

\section{E. KESIMPULAN}

Berdasarkan hasil penelitian yang sudah didapatkan, maka penulis dapat menarik kesimpulan bahwa strategi respon krisis yang digunakan oleh pemangku kepentingan pada pemberitaan di media lokal Solopos dan Joglosemar tidak mempunyai perbedaan yang signifikan. Dalam penelitian ini, strategi respon krisis yang banyak ditemukan adalah kategori Attack the Accuser atau masuk ke dalam cluster deny respon strategy. Baik media Solopos maupun Joglosemar sama-sama mempunyai presentase yang paling tinggi pada kategori tersebut. Pada Solopos sebanyak 22 respon dengan presentase 28,9\%. Sedangkan pada Joglosemar sebanyak 12 respon dengan presentase $31,5 \%$. Respon terbanyak kedua yakni excuse juga termasuk ke dalam cluster deny respon strategy. Solopos dengan 19 respon dan memperoleh presentase sebesar $25 \%$. Joglosemar dengan 6 respon dan presentasenya adalah 15,7\%.

Strategi respon krisis yang dipilih oleh pemangku kepentingan di Keraton Surakarta menunjukan organisasi tidak menyangkal jika mempunyai masalah yang belum dapat terselesaikan. Selain itu, respon dalam kategori menyangkal juga dapat digunakan untuk menjelaskan faktorfaktor terjadinya krisis. 


\section{F. SARAN}

\section{Media Massa}

Media Massa baik online maupun elektronik diharapkan dapat lebih memperhatikan pesan - pesan yang akan disampaikan kepada masayarakat terutama masalah krisis organisasi.

\section{Pemangku Kepentingan}

Untuk pemangku kepentingan dalam hal ini pihak keraton diharapkan lebih berhati-hati untuk mengeluarkan statement di media pada saat krisis terjadi.

\section{DAFTAR PUSTAKA}

Coombs, W T (2007). Protecting Organization Reputation During a Crisis : The Development and Application of Situational Crisis Communication Theory. Corporate Reputation Review vol-10, No 3, PP.163-176

Coombs, WT, Frandsen, F., Hollay, S.J \& Johansen, W (2010). Why Concern for apologia and crisis communication/ Corporate Communication : An International Journal,15:4, 337-349

Eriyanto (2011). Analisis Isi Pengantar Metodologi Untuk Penelitian Ilmu Komunikasi dan Pnelitian Ilmu-ilmu Sosial Lainya.Jakarta : Kencana Prenada Media Grup

Rometi \& Valentini (2010). Alitalia's Crisis in The Media-A Situational Analysis. Corporate Communication : And Internasional Journal Vol.15 No 4, 2010 PP 380-395 